\title{
Church Autonomous Conflict Between GMIM and KGPM in Minahasa (1933-1982)
}

\author{
$1^{\text {st }}$ Yohanes Burdam \\ History Education Department \\ Faculty of Social Science \\ Universitas Negeri Manado \\ Manado, Indonesia \\ yohanesburdam@unima.ac.id \\ $4^{\text {th }}$ Max L. Tamon \\ History Education Department \\ Faculty of Social Science \\ Universitas Negeri Manado \\ Manado, Indonesia \\ maxtamon@unima.ac.id
}

\author{
$2^{\text {nd }}$ Aldegonda Evangeline Pelealu \\ History Education Department \\ Faculty of Social Science \\ Universitas Negeri Manado \\ Manado, Indonesia \\ aldegonda_pelealu@unima.ac.id
}

\author{
$3^{\text {rd }}$ Aksilas Dasfordate \\ History Study Program \\ Fakultas Ilmu Sosial \\ Universitas Negeri Manado \\ Tondano, Indonesia \\ aksilas.unima@gmail.com
}

\begin{abstract}
This investigation is done in order to explain the process of autonomous struggle of Prostestant Chruch in the beginning of 20th century in Minahasa, and the factor affecting the refuse of Minahasan intellectual towards the interference of Indische Kerk in the process of the autonomy of Protestant Church and the cause of problem happened between GMIM and KGPM in between 1933 - 1982 in Minahasa. This research used structural approach by Christopher Llyod, ad historical method by Marc Bloch. Data collection was done through documentary study and interview. The data collected from the archive and interview result of historic criticism, and was interpreted into facts that later strung up into a historical narrative of the researched conflict. From the research finding, it can be drawn that the process of autonomous struggle of Protestant Church in Minahasa, begun personally, then in group and last the organization called "Faithful Base" was established. Although the struggle gets pressure from Indische Kerk, but eventually the Minahasan Intellectual supported by Indonesian Nationalist was successfully established the "The Density of Protestant Church in Minahasa" in April 1933 in Wakan Village, Southern Minahasa. Whereas Indische Kerk a year later in September 1934 announced officially the establishment of "Christian Evangelical Church in Minahasa" in Tomohon.
\end{abstract}

Keywords-Conflict, GMIM, KGPM, Minahasa

\section{INTRODUCTION}

Conflicts that are often negatively seen regardless of "the church autonomous conflict between GMIM and KGPM in Minahasa (1933-1982)", which become investigation topic for this research. The conflicts must be seen positively by the conflicted parties. Because in a conflict there is usually interest that each party stands and struggle for that brings out different thoughts towards conflict existence. As the cause of different perspectives, it affects the life of people staying around this conflict area as happened in Minahasa pertaining to the conflict in this investigation. According to [1], that conflict occurred in Minahasa, is caused by the distinguished perspective between intellectuals and Indische Kerk about the effort of establishing the autonomous church for the protestant congregations as the work result of Nederlandsche Zendellingen Genootschape (NZG) in Minahasa. to Minahasan Intellectual, autonomous church is a church that should be planned and established by effort of Minahasan People. Because by the autonomous church, the intellectual expect for any interest that has not been succeeded in Indische Kerk environment, would be embodied. Meanwhile, Indische Kerk desired that the autonomous church would be in its authority. Distinguished interests in both sides became an obstructive factor in reorganizing Protestant Church in Minahasa, moreover Minahasan Intellectual were supported by their nationalism that they had from Partai Nasional Indonesia (PNI) or Indonesian National Party [2].

Distinguished opinion when it motivates the intellectual establish the organization "Pangkal Setia (Faithful Base)", to fight for acknowledgement on their status and rights in working, beside struggling for the establishment of autonomous church. Charles Tilly, in "collective action" theory, states that in the conflict, there is organization to fight for the interest, because through organization that can be mobilized by power and fund to create collective action. In its process, there would surely be pressure and threats using power and facility from the ruler, but there is still opportunity to have the collective action [3]. The pressure in this theory is also experienced by Minahasan intellectual from Indische Kerk in Minahasa as well as Kerkbestuur in Batavia. Yet, Minahasan Intellectual keep on doing the action through organization "Faithful Base" as the place of struggling.

From several opinion presented pertaining to autonomous church conflict between GMIM and KGPM in Minahasa (1933-1982), a picture was gained that actually the effort of establishing autonomous church from Intellectual in Minahasa, cannot be separated from the enthusiasm started in the beginning of 20th century. At that time, national movement of Indonesia is taking place, and the impact to the Minahasan intellectual was the refuse of any interference of Indische Kerk in establishing autonomous church in Minahasa. However, between Minahasan intellectual inside and outside of Indiscche Kerk's bureaucracy structure, there is was still different point of view. 


\section{RESEARCH METHODS}

The approach used in this research were structurism and structuristic. According to [4], struturistic approach combines the bases of phenomenon approach and structural approach, which are unique things (in phenomenon approach) with universal things (social structure in structural approach). It also employs hermeneutic to explain causal factor, and the form of the story to complete the analysis by employing concepts to build theories or models [5]. The problem researched by using the first structuristic, can be started from an event, without avoiding the structure where the event takes place; secondly, it can be started from social structure without disappearing the event that contains active element; and thirdly, ideally, the researched problem is started from the whole happenings; from social structure or event [4]. Data collection and analysis method used was historical method by [6]; where the collected data was categorized into: (a) Generalizing, and or (b) categorizing. These ways were used based on the concept of becoming "construction material" from the theory that basses the fact explanation which is "collective action" by [3], that interest causes conflict, organized to mobilize power and fund so embody the collective action, although there will be pressure; and the theory of conflict by [7], in one of its proportion, that a conflict is taking place longer because each sides especially followers, do not know the purpose of conflict.

\section{RESULTS AND DISCUSSION}

Evangelism and Education undertaken by Evangelical Agency (Nederlansche Zendelingen Genootschape-NZG) in 19th century in Minahasa, has succeeded forming the congregations of Protestant Christian and numerous graduate, in the field of church service or zending schools. But, in the middle of 19th century, NZG experienced the lack of funding in taking care the congregations and school they had built. Therefore, the congregations were handed over to Indische Kerk, yet those who were in zending school got the discriminative treatment compared to those who were in Indische Kerk bureaucracy structure. Therefore, teachers fought for status acknowledgement and rights on their occupation and demanded for establishing autonomous church outside of Indische Kerk's authority. Teachers that were called intellectual in this investigation, later organized themselves and keep on fighting until The Density of Protestant Church in Minahasa was finally established in April 1933. Meanwhile Indische Kerk formed and officially announced the establishment of "Christiain Evangelical Church in Minahasa" in September 1934. Because of historical background of both churches in Minahasa, later happened long time taking conflict. From the research finding, the conflicts were covering: (1) the fighting process of autonomous church in the beginning of 20th century; (2) causal factors of the intellectual refuse towards Indische Kerk's interference in establishing the autonomous church; and (3) the cause of conflict between GMIM and KGPM from 1993 to 1982.

\section{A. Struggling process of autonomous church in the} beginning of 20th century in Minahasa.

The struggle of autonomous church in the beginning of 20th century was different from the struggle in the late of 19 th century. In the beginning of 20th century, the struggle was in the form of committee and zending teachers that later were organized in "Faithful Base". While in the late of 19th century, the struggle was in the form of personal as done by Lambertus Mangindaan. But, the continuance of struggle idea of autonomous church is still kept. This appears by the name of "Faithful Base", that faithful to the basic struggle Lambertus Mangindaan has done, which is "autonomous church" in Minahasa.

Facing the demand of the establishment of autonomous church by Pangkal Setia (Faithful Base) in Minahasa, so the comission V and XII were established by Kerkbestuur. But, both of these commissions in the first years did not bring about church regulation and agreement about the recondition of church leader, which would take place in Minahasa. The reason is because the replacement several members of commission that were not able to work side by side [8]. This is why the leader of Indische Kerk in Minahasa, and not the actual situation. Because it was not the member who were not corporative, but the members did not agree to de Vreede's thought, which puts Indische Kerk's interest as priority rather than native's demand.

The attitude of the priest chief in Minahasa or Kerkbestuur in Batavia, were actually not faithful in reconditioning the church in Minahasa. On one side, Indische Kerk did not yet trust the native to lead church organization. On the other side, the attitude of Indische Kerk, which is reluctant in handing over church leadership to native, for it would destroy their dominance, and cause the disappearance of authority of colonial government in Minahasa. It can be known by the De Vredee's written explanation about "church regulation", which was proposed to kerkbestuur, that if there was no confirmation in the regulation, meaning who deserves to be chosen to be leader in church, then Indische Kerk, would surely fail, and let the Minahasan be freed with their attitude. Freedom and attitude meant the willing of the native to freely rule in church, and so, the wanted the establishment of autonomous church for Minahasan. The worry of Indische Kerk, was reasonably, because that was the willing of the intellectual through Faithful Base organization.

At this point, the reaction of suppress between Indische Kerk with the intellectual in Faithful Base. The reaction of Indeische Kerk's board was open-ended and close-ended undertaken, as well as Faithful Base. Secretly, priest chief of Indische Kerk, De Vreede, discussed with the zending prominent teachers. It was meant for Kerkbestuur to support their fight in reorganizing autonomous church in Minahasa. Besides, De Vreede, created secret reports to Kerkbestuur in Batavia, about the attitude and activities of the assembly that got the support from some people of zendling. It was meant that Kerkbestuur support its struggle in Minahasa, and expect the opposite which are the member of commission $\mathrm{V}$ and XII, to be fired, for instance, J.U. Mangowal [9]. Although the struggle of the intellectual in establishing autonomous church in Minahasa through Faithful Base, had not succeeded yet, but they kept on trying, for instance in education field. In this field, it was recorded that they were successful. NZG institution was again entrusted to handle the education, especially in increasing the number of theological lecturers, so that STOVIL (School Tod Opleiding coor Inlands Leraar) could be increased to be clergyman school. Their effort, later become the outset of Faculty of Theology University of Indonesian Christian in Tomohon [8]. 


\section{B. Causal factor of the refuse of Minahasan Intellectual towards Indische Kerk}

The refuse of Minahasan Intellectual towards Indische Kerk's interference in establishing the autonomous church in is caused by the interest of Indische Kerk itself, and the interest of the intellectual which was autonomous church demand and nationalism enthusiasm.

\section{a. Interest factor of Indische Kerk}

"Indonesian Protestant Church", which was better known as Indische Kerk, its appearance in Dutch Indie in 19th century, is relating to the re-ruling of Dutch on its colonial area, which was ruled by the British. After took over the colonial area from the British in 1811, and followed by the reconcilement of both sides in August 31st 1814, in 1815 all of the colonial areas in Indonesia was given back to the Dutch by the British. Minahasa area itself, was just given up on April 1817 [8].

While Dutch colonial government re-ruled again, there was attitude change that the Indonesian society needed to be improved every way. For instance, in religious field, government had no longer felt itself as a Christian Ruler as in VOC era [8]. Actually, that attitude had ever existed in Daendel's governmental era (1805-1811), through the proclamation of freedom to be a part of certain religion, and the freedom itself become more inclusive in Raffles' governmental era (1811-1816) from England. The attitude change was a door for the evangelical agency to enter Indonesia. Yet, in that inclusive situation, as the matter of fact, nation was still interfering in terms of religious activity, and was not being neutral towards religions in Indonesia [10].

Dutch colonial government, did not implement the opened attitude in religious freedom, which is continued from Deanderls' and Raffles' governmental era. At the time, there were two factors, considered by the government. Firstly, as the heirs of the congregation taken care by VOC, government could no longer merely release these congregations. Government has the sense of taking care of them. Secondly, the government realized, that the moslem were having more of striving attitude against the Dutch, compared to the Christians. So, the government made efforts to prevent this second factor, with directing the activity of christianizing to the regions, which still had the cultural religion, and not in the area that were moslem already [10]. Meanwhile, first consideration boosted the government to establish GPI. That motivation, as expected by Willem I, as Dutch King at the moment to end the faith disunity in Protestant. By utilizing the national authority, Willem I had a plan to unify churches in his governmental territory. The ideal, in Netherland, could not be succeeded. Therefore, as ruler of colonial are, a king's decree was announced, that since 1815 any ecclesiastical activity would be handled by Ministry of Colonial Territory [11].

To Indonesia, the decree had just been implemented in 1835 , though the establishment a 'unified church', which is the unity of all protestant congregation, such as GPI, as an independent church from any church in Netherland (B.A. Suak, 1992:21). This church is structurally and financially tied to colonial government, so varied effort to embody the church re-organization were not successful (Zakaria J. Ngelow, 1996:216). This church was led by a church committee (Kerbestuur), which were appointed and inaugurated by General Governor. The chief of this church, must be the one who sits in high place in national apparatus (Dutch Indie Council). Besides, there were members of committee consisted of protestant priests, three prominent members of congregation. All of them stayed in Batavia which was the central of Indische Kerk (B.A. Suak, 1992:22). Relating to the decree of the chief position of church committee, it was impossible for Indonesian to have this position. As proven, they could only be the board members. At the time, Kerkbestuur's position was just an advisor, for the appointment and the placement of priest, were the right of the General Governor, as they proposed. General Governor was in command of all things that had been certainly decided by Kerkbestuur, including the congregation board. Therefore, chucrh functionaries that took care of the congregation, also worked in accordance to the hierarchical board order [12].

Functionaries in Indische Kerk's structure, consisted of: the highest position, was "priest" (predikant), one positions lower than that were the church servant that used to work for zending, which called "assistive priest" since 1867, and in 1937 they were called Indie Priests (Inlands-predikant). Both of these positions were stated by the European. On the third position, was a position for Indonesian which previously called "penulung" or assistant (hulp-zendeling), which later in 1881were called 'Indigenous Pastor' (Inlands -Leraar). Lower than that were teachers of congregation, which generally took over the responsibility as zendling school teachers. From priest position, assistive priest and native priest, all of them became officer, and were paid by nation, were also included in official structure of Indische Kerk, led by Kerkbestuur. The teacher of congregation is paid by NZG in relation to the responsibility as zending teacher, and not as teacher of congregation [12]. From this structure, the teachers of congregation and other zending teacher were out of church responsibility, although they did their task in congregation (church).

The relationship between Indische Kerk and Hercormd church in Netherland, were going on through a commission called "Haagsche Commissie", consisted of seven priests. The task, was to advice and had right to provide the needs, examined and to inaugurate the priest staff that would be sent to colonized area. But, this commission could not do more, for the task needed to be approved by the minister of colonial area.

b. Factor of autonomous church demand and nationalism enthusiasm

Dissatisfaction towards Indische Kerk in Minahasa, was directly related by establishing the independent church (autonomous). This attitude emerged from the intellectual, which was not agree to the foreign denomination in church leadership in Minahasa [8]. This condition, especially in Minahasa was caused by Indische Kerk's structure that did not give place to zending teacher, and teacher of congregation in terms of either position or attention for their right (wage).

The intellectual's attitude that resist either De Vreede in commission XII or Indische Kerk's leadership in Minahasa, by its effort to determine or to arrange church regulation by itself. Because, after he first meeting of the committee, there was no longer further meeting. It could be observed in a letter by A.F. Najoan, questions the vacuum of the 
commission to De Vreede. He questioned, whether the commission XII was "alive or dead", because according to him, lots of questions had come from the society about the outcome of the commission. Thus, letter from j. Jacobus to GPI in Batavia, it was written that GPI conference during 1929 and 1930, which was implemented along with the chief priests of commission and assistive priest, could not present all the related elements, for funding issue. The board had a notion, that in the future the completed commission structure, would be expected in terms of giving autonomous authority as much as possible to the Hindia church. The letter clearly stated that the member of other commission such as J. Jacobus would not be included, because the financial issue. But, actually what asked was the response from Indische Kerk toward De Vreede's report about "church regulation" in the conference taken place at Batavia. The regulation would later be the base or foudation to establish church organization in Minahasa. The demand was based on reality, that the proposed regulation was De Vreede's longing, and was not the result of deliberation as expected from the establishment of commission $\mathrm{V}$ an XII.

Meanwhile, Faithful Base Association and its activities, especially related to the establishment of autonomous church in Minahasa, had raised different reaction from Inische Kerk and Dutch Colonial Government. Indische Kerk's reaction was one by the chief priest in Minahasa, through church bureaucracy, that essentially reflected attitude of not yet believing the native in church leadership in Minahasa. While Dutch colonial government showed the attitude of giving the chance to the church re-organization. Because this effort was determined Dutch government in Netherland, to be implemented to colonized area, which was the separation between nation and church. Moreover, colonial government of Dutch Indie itself, expected the plan of church reorganization would be able to lighten the governmental burden in terms of funding.

The effort to re-organize the church did not only experience the obstruction caused by distinguished point of view between Indische Kerk with zending and the intellectual, also with the government. It happened, because the Indische Kerk's committee, has treated the church organization as a tool not only to control the society but also to embody their personal interest, which was to own the facility and good wage from the government. Meanwhile, Minahasan intellectual supported by nationalism enthusiasm kept on fighting to make the church independent. The nationalism attitude of Minahasan intellectual was an influence from Indonesian National Party which already entered Manado and Minahasa.

\section{The cause of conflict between GMIM and KGPM in 1933-1982}

By the establishment of KGPM and GMIM the conflict between the intellectual and Indische Kerk should've done, for the effort of establishing the "autonomous church" in Minahasa had been completed. In fact, the conflict kept going on. It was because both churches had different historical background. So, cannot be avoided, that in the conflict was filled by the background of both churches [8]. The issues that emerged between KGPM and Indische Kerk, later went on into between KGPM and GMIM. The inharmonic relationship was not happening in all congregation, and not also the treatment from all priest that serve the GMIM congregation [8].
What really is the problem between these churches. Conflict after the establishment of GMIM was caused by the desire to be the "leader" (leader in church organization and congregation service), and ownership claim of "congregation member" [13]. Because, with the congregation, there would be church board structure, which needs organization leader and servant, called church staff.

The issue of "church oganization leader", is the result of the emerging of claim from GMIM board, that GMIM organization, is legal in Minahasa, and there was statement from KGPM board, that GMIM is "a church that is given by Kerbestuur, and gift from Dutch Colony" [8]. The act of justifying the legality of this church organization, was based on the desire of the leader, to be seen, and respected as the leader of Protestant church in Minahasa. For example, from the thought, which is presented y Ds. Nieuwpoort in Manado [2], that the people of KGPM supposed to be in GMIM, for it is the only Christian Church, legal in Minahasa. Logically, they which stay out of it, were fragmented sects and churches. KGPM, is the resistant church, competitive church and would opposite with every authority that it owns.

This thought by Nieuwpoort, is not new for KGPM, but because of it is related to the emerging of GMIM, so it affects to the practice of some priests in GMIM congregation. In which there is also KGPM meeting. For instance, in Kakas-Remboken district [14], priest forbids and threats the member of congregation to not make contact with KGPM member, if not, they will be brought to justice. And also, news was spead, that KGPM will soon be dispersed by the government [14].

Discriminative attitude of half GMIM servant in Indische Kerk's environment in Minahasa, happened also in educational field and social service. The priest suppress the KGPM members, to use the name of GMIM. If it is not obeyed by them, their children that go to zendling school, subsidized by the government, will be cast out. And so happened in health service, GMIM members are more prioritized than members of KGPM [14]. The attitude and action of priest their service field, depicts a line of hierarchical leadership of GMIM. Because, in the point of view of chief priest Ds. De Vreede, about the existence of GMIM, as legally admitted by the government in Minahasa, affect the action of the assistive priest in their work field.

\section{CONCLUSION}

As the conclusion of "Church Autonomous Conflict between GMIM and KGPM in Minahasa (1933-1982)", are: (1) The struggling process of the autonomous protestant church in the beginning of 20th century in Minahasa is based on the action of giving up the congregation evangelized by Nederlansche Zendelingen Genooschape (NZG) in 1881 to Indische Kerk that impact the schools and zending teachers in second decade of 20th century has not been completed by the ones who responsible for it. The struggle was previously done by the church council in Manado and zending teachers but later it is organized in Faithful Base in 1915. Through Faithful Base, the struggle for "the equality of status and right" and "the demand of autonomous church" were going on to Indische Kerk and Kerkbestuur at Batavia. Because of different point of view between Indische Kerk, Dutch colonial government and Minahasan Intellectual, so Minahasan intellectual supported 
by their nationalism established an autonomous church namely "The Density of Protestant Church in Minahasa" in April 1933, and Indische Kerk quickly established the "Christian Evangelical Church in Minahasa" in September 1934. (2) Causal factor of the refuse of Minahasan Intellectual towards the interference of Indische Kerk in the process of protestant church autonomy in Minahasa in the beginning of 20th century are: (a) Indische Kerk's action, and (b) the demand of autonnomous church and nationalism enthusiasm of Indonesia. The first factor, Indische Kerk does discriminative action to Minahasan fellow that work at zendling school with those who work in Indische Kerk's structure. While the second factor, the demand of autonomous church has become a strong will for Minahasan intellectual supported by their enthusiasm on nationalism, so the interference either from Indische Kerk or Dutch Colonial government is seen as the effort of colony through church. (3) The cause of conflict between GMIM and KGPM since 1933-1982 is from the historical background of the establishment of both churches. GMIM as the heir church of Indische Kerk inherits the hierarchical bureaucracy of Dutch leadership. While KGPM as the result of Minahasan intellectual struggle, which is supported by their nationalism which autonomously develop the church without Indische Kerk's interference. Because of both sides stand firm on their statement without seeing the the spirit of this era, so the conflict goes on and the intensity depends on development occurs in this era, which was the end of Dutch colony the intensity of conflict increases so in Japanese colony the intensity drastically decreases, and in the beginning of the independence the intensity almost did not emerge.

\section{ACKNOWLEDGMENT}

Thank you to the Dean of Faculty of Social Science Universitas Negeri Manado for supporting this research.

\section{REFERENCES}

[1] Y. Burdam, "Konflik otonomi gereja di Minahasa (1915-1979)." FIB-UI, 2001.

[2] Persatuan Minahasa, "Manado oleh Persatuan Minahasa," Manado, 1933.

[3] T. Charles, "From mobilization to revolution," Reading, AddisonWesley Publ., 1978.

[4] C. Lloyd, Christopher Lloyd, The Structures of History. London: Basil Blackwell., 1993.

[5] R. Z. Leirissa, Pedoman Penyusunan Proposal Untuk Mahasiswa Pascasarjana Program Studi Ilmu Sejarah. Depok: Program Studi Ilmu Sejarah PPS-UI., 1999.

[6] M. Bloch, Pleidooi voor de Geschiedenis of Geschiedenis Als Ambacht. SUN Nijemegen: Nederlandse vertaling., 1988.

[7] L. A. Coser, The Functions of Social Conflict. New York: The Free Press A Division of Macmillan Publishing Co.,Inc, 1964.

[8] B. A. Suak, "The Assemblage of Minahasan Protestant Congregations (Kerapatan Gereja Protestan Minahasa): A Historical Analysis of Its Founding and Development." 1992.

[9] D. De Vreede, "De Predikant Voorzitter Indische Kerk te Tomohon, Geheim-Eigenhandig, 'Rapport over den huidigen toestand in de Minahasa."” GMIM, Tomohon, 1930.

[10] T. Van den End, Ragi carita: 1860-sekarang, vol. 2. BPK Gunung Mulia, 1999.

[11] J. L. C. Abineno, Sejarah apostolat di Indonesia, vol. 1. Diterbitkan oleh Gunung Mulia untuk [Perhimpunan] Sekolah2 Theologia di Indonesia, 1978.

[12] Z. J. Ngelow, Kekristenan dan Nasionalisme: Perjumpaan umat Kristen Protestan dengan Pergerakan Nasional Indonesia, 19001950, 2nd ed. Jakarta: BPK Gunung Mulia.
[13] A. F. Parengkuan, "The Presence, Place and Role of the Christian Evangelical Church in Minahasa in the Midst of the Struggle of the Minahasan Society and Indonesian Nation in the Period of 1934-1979." 1994.

[14] Fikiran, "Fikiran," 25 Juni, Manado, 25-Jun-1938. 